\title{
Dominance and fertility in a functionally monogynous ant
}

\author{
J. Heinze* and T.A. Smith \\ MCZ, Harvard University, Cambridge, MA 02138, USA
}

Received June 28, 1989 / Accepted January 13, 1990

\begin{abstract}
Summary. Colonies of some leptothoracine ants may contain several inseminated but sterile females in addition to a single, fertile queen (functional monogyny). We here report the first observations on the behavior of these supernumerary females in the nearctic ant Leptothorax sp.A, a species belonging to the L. "muscorum" complex.

In four colonies, each with up to eight intermorphic females, ritualized or openly aggressive interactions between individuals were observed, similar to those among workers of some other leptothoracine ants. The responses of individual females during encounters with nestmates apparently reflect the existence of linear dominance hierarchies. In each colony, the highest ranking individual was fed and groomed significantly more often than other females, and was the only one to oviposit after hibernation and to become fully physogastric during the first weeks of spring. When these $\alpha$-females were removed from three colonies, several other females started to lay eggs. However, in each colony only the highest ranking individual remained fertile; the others either were pushed out of the nest and finally killed by the workers, or their ovaries degenerated again.

Aggressive interactions among females may also play an important role in the foundation of new colonies either by inducing intermorphs to leave the maternal nest to found new colonies solitarily or by inducing colony fission.
\end{abstract}

\section{Introduction}

In numerous species of social insects, colonies may contain several inseminated females capable of reproduction. The queens in polygynous nests are not always a homogeneous class of individuals; but their fertility

* New address: Zoologisches Institut, Universität Würzburg, Röntgenring 10, D-8700 Würzburg, Federal Republic of Germany

Offprint requests to: $\mathrm{J}$. Heinze at his new address varies widely. In the nests of some wasp and bee species, reproductive success has been found to be correlated with the individual's rank in a dominance hierarchy (for a review see Fletcher and Ross 1985). By ritualized or open aggression, dominant females may prevent subordinates from ovipositing. If two inseminated females of the paper wasp, Polistes gallicus, cooperate in colony foundation, only the more aggressive one lays eggs, and the other remains sterile (functional monogyny, Pardi 1940 ). In young colonies with several females, ovary size and fertility of individuals correspond to their position in the rank order.

Similarly, in some ant species workers establish dominance hierarchies. In the slave-making leptothoracine ants Harpagoxenus (=Protomognathus) americanus (Franks and Scovell 1983) and Harpagoxenus sublaevis (Bourke 1988), and in the non-parasitic Leptothorax (Macromischa) allardycei (Cole 1981), high ranking workers not only forage less often and receive more food than subordinates, they also show greater ovarian development and lay more eggs.

Fighting and aggression among ant females are known from a number of species (e.g., Evesham 1984). However, that dominance interactions may affect the fertility of individual queens has been demonstrated only in foundress associations of the meat ant, Iridomyrmex purpureus (Hölldobler and Carlin 1985). Young queens engage in ritualized antennation fights and the dominant female oviposits at a significantly higher rate. In mature colonies, consisting of several thousands of workers, the queens become intolerant of each other's presence and inhabit different areas of the nest (oligogyny, Hölldobler 1962). In many other species of ants, multiple fertile queens remain in close contact throughout their lives. Colonies of leptothoracines, for example, usually nest in preformed cavities, such as hollow acorns, twigs, or rock crevices. In polygynous nests the females can regularly be found in close contact (e.g., Herbers 1986). Queens of Leptothorax (Myrafant) curvispinosus apparently ignore each other and oviposit at similar rates (Wilson 1974). In other leptothoracine species, however, only 
one of numerous inseminated females within a colony is fertile and the others are sterile. In contrast to functional monogyny in wasps, in functionally monogynous colonies of leptothoracine ants, the presence of inseminated but sterile females in addition to a single fertile queen is not a transient phenomenon, restricted to a short period after pleometrotic colony foundation (Buschinger 1974a). In the nests of the xenobiotic genus Formicoxenus (Buschinger and Winter 1976; Buschinger 1979; Buschinger et al. 1980) and the non-parasitic species Leptothorax (s.str.) gredleri (Buschinger 1968a) and L. (s.str.) sphagnicolus (Francoeur 1986), supernumerary females can be found throughout the year. They presumably are daughters of the fertile queen that have returned to the colony after mating (Heinze and Buschinger 1988). Their ovaries remain completely undeveloped and usually don't show any sign of egg production. Previously sterile females may become fertile after the old queen's death (Buschinger 1968a; Heinze and Buschinger 1988).

Nothing is known about the behavior of females in functinally monogynous colonies and how monogyny is maintained. We here report the first results on behavioral repertories, dominance interactions, and fighting among females in a functionally monogynous ant, a recently discovered but as yet undescribed leptothoracine, Leptothorax (s.str.) sp.A.

\section{Materials and methods}

Leptothorax (s.str.) sp.A is a common ant in open coniferous forests in northeastern America and is especially abundant on rocky outcrops along the shores of the St. Lawrence and Saguenay Rivers, Québec, Canada. It belongs to the $L$. "muscorum" or $L$. canadensis complex (Brown 1955); a species description will be prepared by Francoeur et al. as part of the revision of the whole tribe. Leptothorax sp.A can be distinguished from other sympatric taxa by its chromosome number of $2 n=30$, by its long propodeal spines, and by specific isozyme patterns (Heinze 1989a).

Queens of $L$. sp.A may be either gynomorphic, as in most other species of ants (i.e., primarily winged, with a bulky thorax consisting of individual sclerites, separated by furrows or sutures), or intermorphic (i.e., wingless, with a simplified thoracic structure; Heinze and Buschinger 1987). Intermorphic queens, though morphologically similar to workers, are indistinguishable from gynomorphic queens in their internal reproductive anatomy: the ovaries of both consist of six ovarioles and a spermatheca of normal size. As in the slave-making ant, Harpagoxenus sublaevis, the two morphs represent different female genotypes (Heinze and $\mathrm{Bu}-$ schinger 1989).

Leptothorax sp.A apparently is monodomous. Complete colonies were collected in early October 1988 in two different populations in Québec: (1) A (IV-40), B (IV-47), C (IV-68), and D (IV-74) on the rocky outcrops of Colline de l'Anse a l'Eau in Tadoussac (Co. de Saguenay) and (2) E (IV-87) and F (IV-99) in an open, coniferous forest on route 170 , some $5 \mathrm{~km}$ north of St. Siméon (Charlevoix-Est).

Colonies contained up to 12 intermorphic females, and, in addition, the colonies from St. Siméon had several gynomorphs (Table 1). Species were identified by comparing morphological features and isozyme patterns. Voucher specimens are located in the Museum of Comparative Zoology, Cambridge, Mass., USA.

Colonies were initially put into small tube nests for transportation (Buschinger and Heinze 1988); after about 1 week they were transferred into plastic boxes with nests consisting of a plastic frame between two microscope slides, a system well adapted for
Table 1. Composition of the Leptothorax sp.A colonies used for behavior observations

\begin{tabular}{lcll}
\hline Colony & $\begin{array}{l}\text { Intermorphic } \\
\text { females }\end{array}$ & $\begin{array}{l}\text { Gynomorphic } \\
\text { females }\end{array}$ & Workers (ð̆ॅ̆) \\
\hline IV-40 (A) & 8 & - & 25 \\
IV-47 (B) & 5 & - & 60 \\
IV-68 (C) & 10 & - & 60 \\
IV-74 (D) & 12 & - & 40 \\
IV-87 (E) & 7 & 4 & 150 \\
IV-99 (F) & 10 & 3 & 120 \\
\hline
\end{tabular}

the culture of leptothoracine ants (Buschinger 1974b). Observations were started after a shortened hibernation of about 10 weeks at $0^{\circ} \mathrm{C}$ to $5^{\circ} \mathrm{C}$. Until the end of the experiments the colonies were kept either at room temperature or at artificial daily temperature rhythms as described by Buschinger $(1966,1973)$. Every 2 or 3 days, they were fed diluted honey and pieces of insects (mealworms or crickets). Individual females were marked with wires that were tied in different combinations between propodeum, petiole, postpetiole, and gaster (Dobrzański 1966). Four females were marked by cutting off some tarsomeres of the hind legs. The different treatments did not affect their behavior or survival rates. For the presentation of data in this paper, females are named by a combination of a capital letter, designating the colony to which they belong, and a number, indicating their rank in the dominance hierarchy. A rank could not be assigned to some individuals; these are named with a lower case letter instead of a number. Colonies A, B, C, and D were observed for approximately 15 to $25 \mathrm{~h}$ each. We focused on individual females for periods of 30 to $45 \mathrm{~min}$, but simultaneously recorded all other interactions involving females. Colonies $\mathrm{E}$ and $\mathrm{F}$ were observed for approximately $10 \mathrm{~h}$ each. A total of about 10000 acts were recorded, including solitary acts like self-grooming or "resting" and mutual acts like grooming, regurgitation, or brood care. Worker behavior was only qualitatively monitored.

The behavior of individual females during encounters with different nestmates suggested the existence of dominance hierarchies (for the detailed description of dominance or aversion behaviors, see "Results"). Rank orders were determined by arranging individuals in an order that minimized reverse interactions. Due to incomplete information in $\mathrm{C}$ and the small number of interacting females in B, a statistic test of linearity (Appleby 1983) was applied only in colony $\mathrm{A}$. If the ratio of initiated attacks to received attacks differed significantly from a random probability of 0.5 (binomial test, one-tailed, $P<0.05$ ), the more aggressive individual was regarded as dominant to the less aggressive one. If no female was significantly dominant, either due to frequent reversals or to a low number of observed interactions, the relationship was considered unknown.

Both authors independently observed behavior and, where possible, determined hierarchies in colonies A, B, C, and E. Colonies $\mathrm{D}$ and $\mathrm{F}$ were observed only by J.H. In colonies $\mathrm{A}, \mathrm{B}$, and $\mathrm{D}$, 6 to 10 weeks after the end of hibernation, the fertile queen was removed and kept for 2 weeks with three workers and a number of larvae, each in separate nests. For all observations, a Wild dissecting microscope was used. Data were analyzed with an IBM Personal Computer AT, using the ETHOGRAM program, written by D. Gladstein (Carlin et al. 1987).

We dissected females using the method described by Buschinger and Alloway (1978). Some females - B2, C3, C6, Cc, and Cjcould not be dissected until several days after they had died; consequently the condition of their ovaries was no longer visible. Females $\mathrm{Da}$ and $\mathrm{Dk}$ somehow managed to escape from the arena (see "Results") and thus were also lost to science.

The condition of the ovaries was rated using the classification by Buschinger (1968a) and Alloway et al. (1982), modified for the special relations in our colonies (Table 2 ). 
Table 2. Categories of ovarian development in females of Leptothorax sp.A. After Buschinger (1968a) and Alloway et al. (1982), modified

A $\quad \begin{aligned} & \text { Fertile queens. Ovarioles are elongated, corpora lutea } \\ & \text { (remnants of previously laid eggs) are present. In the } \\ & \text { reproductive season they contain numerous eggs with } \\ & \text { white yolk deposits }\end{aligned}$
a $\quad \begin{aligned} & \text { Inseminated females, sterile. No corpora lutea are } \\ & \text { present; ovarioles are short }\end{aligned}$
a $\rightarrow$ A $\quad \begin{aligned} & \text { Inseminated female with elongated ovarioles, eggs in } \\ & \text { development, but no corpora lutea present }\end{aligned}$
$\mathrm{A}_{\text {deg }} \quad \begin{aligned} & \text { Inseminated female with elongated ovarioles, no eggs, } \\ & \text { but some corpora lutea. Apparently females that had been } \\ & \text { laying eggs for a short period of time }\end{aligned}$
C $\quad$ Uninseminated, sterile female
C $\quad$ Uninseminated, but fertile female

We use the functional definition of "queen" in this paper, that is, only fertile, inseminated individuals, regardless of their morphology, are called queens (Buschinger and Winter 1975).

\section{Results}

\section{Colonies with intermorphic females}

Workers and intermorphic females of Leptothorax sp.A perform about a dozen different activities, and there were marked differences between the behavioral repertories of workers, sterile, and fertile intermorphic females. Only workers were observed foraging and cleaning the nest, and they also did the major part of brood care. All females intensively groomed eggs, larvae, and pupae, but only in one case was a female observed feeding a piece of insect tissue to a larva. Usually only workers regurgitated food to females and other workers; feeding of females or workers by other intermorphs was observed only occasionally (Table 3 ).

In all four colonies, females showed aggressive behavior toward each other. We observed ritualized dominance interactions similar to those described for other species of ants, especially Protomognathus, Harpagoxen$u s$, and Leptothorax allardycei.

One form of aggression consisted of a violent antennation of the opponent's head and thorax by the attacking female, often followed by the latter climbing on top of the other. The submissive female usually crouched and froze in response to the antennation. Antennation typically lasted for a few seconds $(4.7 \pm 2.9 \mathrm{~s}, 61$ acts in colony $\mathrm{C}$ ), and the subordinate females remained in a pupa-like posture with legs and antennae kept close to the thorax for up to $90 \mathrm{~s}$ after the attack had stopped. A more severe form of aggression was biting or pulling at the opponent's antennae or extremities, less frequently at the postpetiole or mandibles. Pulling etsually lasted some 10 to $20 \mathrm{~s}(14.5 \pm 12.6 \mathrm{~s}, 31$ acts in colony C), but in a few cases for several (up to 19) minutes. Subordinates apparently avoided dominant females. They either fled approaching females or crouched and retracted their
Table 3. Frequency of grooming and feeding in one colony of Leptothorax sp.A. Interactions between individual workers or between workers and brood were not recorded. In this and two additional colonies the fertile $\alpha$-female (A1) was groomed significantly more often both by workers and females, and fed significantly more often by larvae than any other individual. Female A1 was also fed significantly more often by workers $(P<0.01$, binomial test $)$

\begin{tabular}{|c|c|c|c|c|c|c|c|c|c|}
\hline & A1 & $\mathrm{A} 2$ & $\mathrm{~A} 3$ & $\mathrm{~A} 4$ & A5 & A6 & $\mathrm{A} 7$ & A 8 & б̆̆ㅜ \\
\hline \multicolumn{10}{|l|}{ Groomed by: } \\
\hline workers & 82 & 53 & 45 & 39 & 63 & 2 & 63 & 23 & - \\
\hline$\alpha$-female & - & 2 & 2 & 0 & 0 & 0 & 1 & 1 & 2 \\
\hline other females & 67 & 4 & 7 & 3 & 15 & 3 & 17 & 6 & 62 \\
\hline \multicolumn{10}{|l|}{ Grooms: } \\
\hline worker & 2 & 10 & 5 & 1 & 27 & 1 & 17 & 2 & 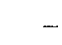 \\
\hline$\alpha$-female & - & 15 & 17 & 0 & 11 & 2 & 16 & 6 & 82 \\
\hline other females & 8 & 33 & 0 & 2 & 14 & 2 & 4 & 1 & 288 \\
\hline brood & 44 & 46 & 50 & 28 & 27 & 45 & 48 & 46 & 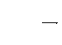 \\
\hline
\end{tabular}

Regurgitates food to:

$\begin{array}{lllllllllr}\text { workers } & 0 & 0 & 0 & 0 & 0 & 1 & 1 & 0 & - \\ \alpha \text {-female } & - & 0 & 0 & 0 & 0 & 0 & 0 & 0 & 28 \\ \text { other females } & 0 & 0 & 0 & 0 & 0 & 1 & 0 & 0 & 28\end{array}$

Solicits food from:

$\begin{array}{lrllllllll}\text { worker } & 28 & 5 & 4 & 2 & 6 & 2 & 7 & 2 & - \\ \text { female } & 1 & 0 & 0 & 0 & 0 & 0 & 0 & 0 & 2 \\ \text { larvae } & 32 & 2 & 1 & 0 & 0 & 0 & 2 & 0 & -\end{array}$

Proctodeal feeding

\begin{tabular}{lllllllll}
10 & 3 & 1 & 2 & 2 & 2 & 2 & 0 & 2 \\
\hline
\end{tabular}

antennae when coming near a higher ranking individual. It is not known how the rank was recognized in these cases.

The behavior of individual females during encounters with other ants indicates the existence of dominance hierarchies in $\mathrm{A}, \mathrm{B}$, and $\mathrm{C}$ (Tables 4-6). In colony $\mathrm{D}$, apparently several individuals (D2, D3, Da, Dh, Dk, and Dm) were of similar rank, and their interactions frequently escalated to fights (Table 7). Attacks in a reversed direction occurred in $\mathrm{A}$ in $3.6 \%$, in $\mathrm{B}$ in $5.1 \%$, and in $\mathrm{C}$ in $3.5 \%$ of all observed interactions between females, but about half of them were followed by violent attacks in the typical order shortly after. According to Appleby (1983), there is a high probability that linear or near-linear hierarchies will arise from random relationships in small groups of individuals: no hierarchy in a group of less than six individuals can have a statistically significant level of linearity. In colony A, the low number of observed interactions prevented us from inferring a statistically significant dominance of $\mathrm{A} 1$ and $\mathrm{A} 2$ over $\mathrm{A} 8$, or of $\mathrm{A} 3$ over $\mathrm{A} 5$ (binomial test, one tailed; Table 4). The hierarchy observed in colony A therefore has approximately a 0.07 probability of originating by chance.

In the first weeks after the end of hibernation, the one or two highest ranking females initiated a major part of the dominance displays: A1 and A2, about $50 \%$; $\mathrm{B} 1,39 \%$; $\mathrm{C} 1$ and $\mathrm{C} 2,79 \%$. Aggression was frequently directed toward the female immediately below in rank: 
Table 4. Frequency of aggressive interactions in intermorphic females and workers of Leptothorax sp.A, colony A from Tadoussac, Québec. Violent, unanswered antennation, climbing on top of the opponent, or tearing on her extremities are summed as "attacks." Observations were started directly after the end of hibernation and continued for about 10 weeks. The total observation time was $18 \mathrm{~h}$. The higher ranking individual attacked the lower ranking one significantly more often than vice versa (binomial test, one tailed, $P<0.05$ ), except in the cases circled. $\mathrm{QR}=$ queen removal

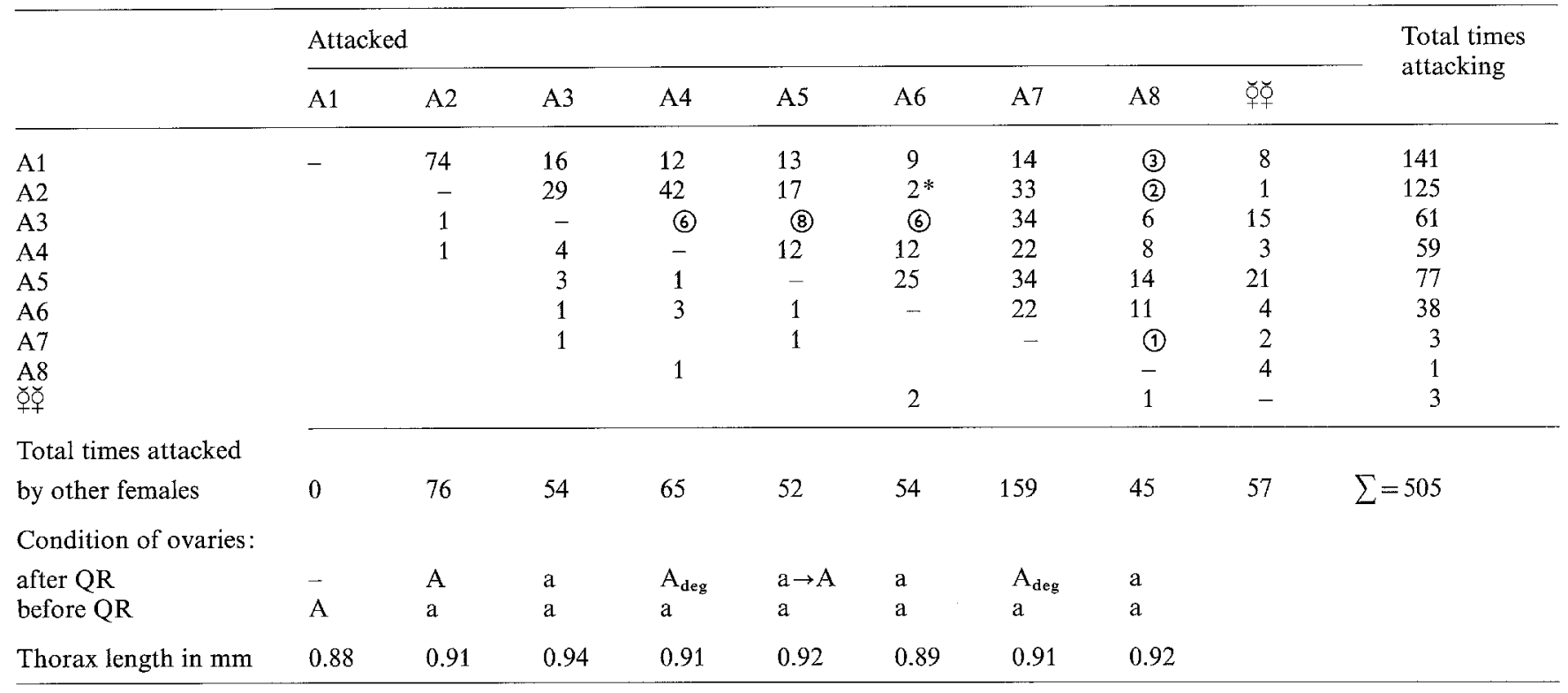

in colony $\mathrm{B}$, in $61 \%$ of all interactions a female dominated an individual that immediately followed in rank. In colony $\mathrm{A}$, the low ranking female $\mathrm{A} 7$ was attacked by the more dominant individuals at a rather high rate (Table 4), but still $33.4 \%$ of all attacks involved individuals immediately following each other in rank.

In all four colonies only the $\alpha$-females (A1, B1, C1, and D1) became visibly physogastric and were observed laying eggs. They started ovipositing within about 2 or 3 weeks, but became fully physogastric only after approximately 5 weeks. In colony $\mathrm{D}$, which could not be observed extensively until 6 weeks after hibernation, the fertile female D1 rarely took part in aggressive encounters with the other females and was observed dominating only four times.

All $\alpha$-females were groomed significantly more frequently than individual workers or other females (binomial test, $P<0.01$ ), and they were groomed both by workers and high or low ranking females (Table 3). In each colony the highest ranking individual received food from larvae and workers at a higher rate than other females or workers (Table 3 ).

In colonies $\mathrm{A}$ and $\mathrm{C}$ the $\alpha$-females were also more often fed by "proctodeal feeding" (binomial test, $P<$ 0.01 , Table 3). In Leptothorax sp.A, workers lay trophic eggs, which are fed to larvae or eaten by nestmates. We observed that prior to oviposition, workers flexed the gaster below the thorax, protruded the stinger, and secreted droplets of a whitish fluid that were eaten by high ranking females, sometimes by other workers, and once by the secreting worker herself. Similar behaviors have been described among the Dolichoderinac (e.g., Torossian 1958) and in the myrmicine Zacryptocerus varians (Wilson 1976). In Dolichoderus quadripunctatus, the
Table 5. Frequency of dominance interactions in intermorphic females and workers of Leptothorax sp.A, colony B. The colony was observed starting directly after the end of hibernation for approximately $15 \mathrm{~h}$. Female B2 died 8 weeks after the beginning of the observations. In all cases, the higher ranking female attacked the lower ranking one significantly more often than vice versa (binomial test, one tailed, $P<0.05$ )

\begin{tabular}{|c|c|c|c|c|c|c|c|}
\hline & \multicolumn{6}{|c|}{ Subordinate female } & \multirow{2}{*}{$\begin{array}{l}\text { Total times } \\
\text { dominating }\end{array}$} \\
\hline & B1 & B2 & B3 & B4 & B5 & б두 & \\
\hline B1 & - & 93 & 7 & 14 & 16 & 4 & 130 \\
\hline B2 & & - & 39 & 28 & 20 & 10 & 87 \\
\hline B3 & & 1 & - & 39 & 22 & 7 & 62 \\
\hline B4 & & 1 & 3 & - & 22 & 16 & 26 \\
\hline B5 & & 6 & 1 & 3 & - & 8 & 10 \\
\hline ㅎ̆ & & 1 & & & & & 1 \\
\hline
\end{tabular}

Total times

dominated by

$\begin{array}{llllllll}\text { other females } & 0 & 101 & 50 & 84 & 80 & 45 & \sum=315\end{array}$

Condition of ovaries: $\begin{array}{llllll}\text { after } Q R & - & ? & \mathrm{~A} & \mathrm{c} & \mathrm{A}_{\text {deg }} \\ \text { before } \mathrm{QR} & \mathrm{A} & ? & \mathrm{a} & \mathrm{c} & \mathrm{a}\end{array}$

Thorax length

$\begin{array}{llllll}\text { in } \mathrm{mm} & 0.97 & 0.92 & 0.94 & 0.95 & 0.94\end{array}$

fluid has been identified as the yolky remnants of abortive trophic eggs (Torossian 1978).

\section{Emigrating females}

In contrast to colonies $\mathrm{A}$ and $\mathrm{B}$, some females in colony $\mathrm{C}$ and especially in colony $\mathrm{D}$ left the nest, perhaps trying 
Table 6. Frequency of dominance interactions in intermorphic females and workers of Leptothorax sp.A, colony C. The colony was observed starting directly after hibernation for approximately $15 \mathrm{~h}$

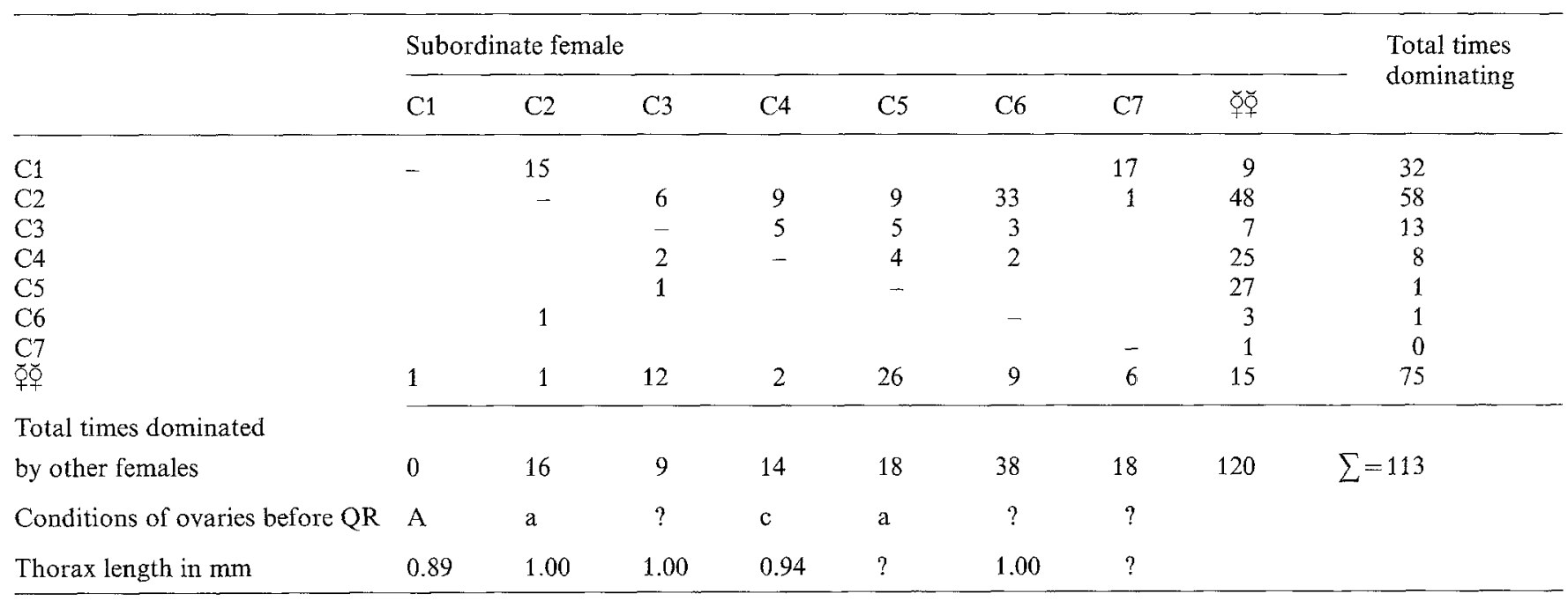

to establish their own colony. When placed into an arena with an area of $40 \mathrm{~cm} \times 25 \mathrm{~cm}$, where several empty nesting sites were provided, $\mathrm{Da}, \mathrm{Dh}$, and $\mathrm{Dk}$ did not return to the colony. Before emigrating, some females, such as $\mathrm{Da}$ or $\mathrm{Dk}$, had attacked most females that remained in the original nest. The emigrating females themselves were attacked at least once only by the $\alpha$-female, other high ranking intermorphs, other emigrating females, or workers (Table 7).

Some females - D2, D3, and Dm - entered and left the colony several times a day. When entering the nest, these females vigorously antennated all workers they encountered and frequently pulled at their antennae or legs. On the other hand, workers often initiated aggressive interactions by first cautiously antennating the female and then pulling on her extremities or postpetiole (Table 7, Fig. 1). Worker aggression was answered by the female with violent domination and often resulted in mutual antennation bouts, followed by the worker and female simultaneously pulling on each other's appendages. During these fights, females and workers flexed the gaster as if trying to sting. No actual stinging was observed, though the stinger was actively protruded. In contrast to female-female dominance interactions, in female-worker encounters other workers interfered and sometimes the female was pulled by four or more workers for several minutes. Attacks, interrupted by periods of grooming, usually lasted for the whole observation period or until the female left the colony.

During the returns into their mother's nest, the high ranking females D2, D3, and Dm usually ignored the fully physogastric D1, and vice versa, and they were avoided by the more subordinate females D4, D5, and D6 (Table 7). Once Dm briefly attacked D1; this was the only encounter during which a queen was antennated without fighting back. When two of the higher ranking females met, they either briefly antennated each other and then both backed off, or they severely fought. Fights between females lasted only for 2 or $3 \mathrm{~s}$, after which both females fled from each other and often left the nest. Fights between females or between females and workers tended to alarm the whole colony: workers would start to move around and to carry larvae and eggs, and in some instances the queen abandoned the egg pile and moved about the nest. Following two of the fights among D2, D3, Da, and Dk, the queen D1 left the colony, but was pulled back into the nest by workers. During periods of disturbance, an aggressive female, such as D3 or Dm, was occasionally the only female near the brood pile for up to half an hour.

\section{Queen replacement}

After 6 to 10 weeks of observation, the fertile $\alpha$-female was removed from colonies $\mathrm{A}, \mathrm{B}$, and $\mathrm{D}$. Afterwards, the aggression among workers in all three colonies in-

\section{aggression initiated by workers and directed toward}

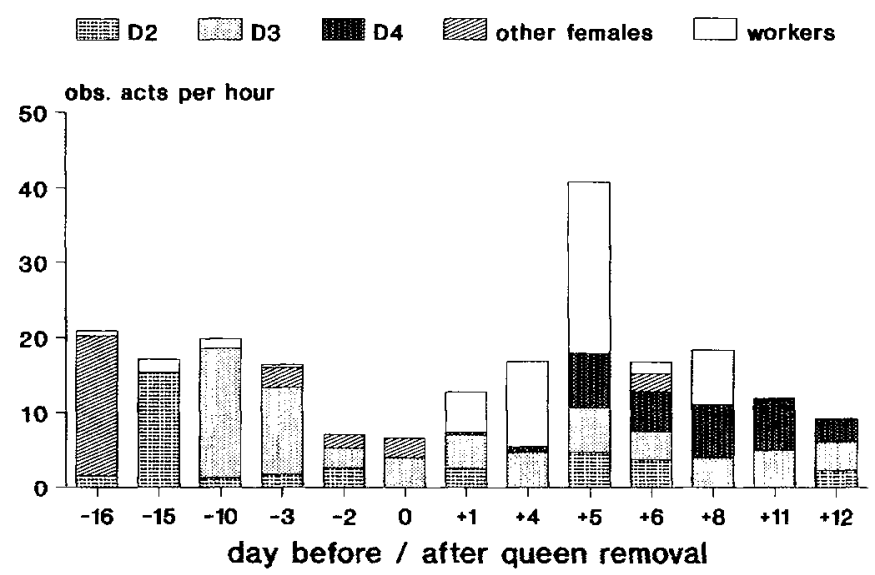

Fig. 1. Frequency of aggression in colony D. Shown are aggressive acts initiated by workers and directed toward individual intermorphic females or other workers, before and after the fertile queen was removed. Female D4 was killed by workers on day +12 
Table 7. Frequency of fighthing and dominance interactions between intermorphic females of Leptothorax sp.A, colony D, before and after the fertile $\alpha$-female was removed. The number of fights are encircled. The colony was observed starting 6 weeks after the end of hibernation; the fertile queen was removed 6 weeks later. $\mathrm{Da}, \mathrm{Dh}, \mathrm{Dk}$, and $\mathrm{Dm}$ had permanently left the colony when $\mathrm{D} 1$ was removed

Before queen removal:

\begin{tabular}{|c|c|c|c|c|c|c|c|c|c|c|c|c|}
\hline & \multicolumn{11}{|c|}{ Subordinate female } & \multirow{2}{*}{$\begin{array}{l}\text { Total times } \\
\text { dominating/fighting }\end{array}$} \\
\hline & D1 & $\mathrm{D} 2$ & D3 & D4 & D5 & D6 & $\mathrm{Da}$ & $\mathrm{Dh}$ & Dk & $\mathrm{Dm}$ & 龺军 & \\
\hline D1 & - & & 2 & & & & 1 & & & 1 & & 4 \\
\hline D2 & & - & & 7 & 3 & 5 & 1 & 3 & 8 & & 37 & $27 /(24)$ \\
\hline D3 & & (6) & - & 2 & 3 & 2 & 1 & & 3 & & 54 & $11 /(13$ \\
\hline D4 & & (4) & & - & & & & & & & 1 & (4) \\
\hline D5 & & $2 /(2)$ & & & - & & & & & & & $2 /(2)$ \\
\hline D6 & & & & & & - & & & & & 1 & 0 \\
\hline $\mathrm{Da}$ & & $1 /(5)$ & $1 /(5)$ & 2 & 9 & 3 & - & 1 & 4 & & 7 & $21 /(11)$ \\
\hline $\mathrm{Dh}$ & & (1) & & & & & 2 & - & & & & $2 / 3$ \\
\hline Dk & & & & 1 & & & 1 & (2) & - & & & $2 /(2)$ \\
\hline $\mathrm{Dm}$ & 1 & (6) & $1 /(2)$ & 1 & 1 & 1 & $1 /(1)$ & & & - & 54 & $6 / 9$ \\
\hline 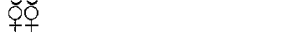 & $(2)^{\mathrm{a}}$ & $26 /(4)$ & $45 /(4)$ & & & & 10 & 1 & & $29 /(12)$ & 5 & 113/@ \\
\hline \multicolumn{13}{|l|}{ Total times dominated } \\
\hline by other females & 1 & 3 & 4 & 13 & 16 & 11 & 7 & 4 & 15 & 1 & & $\sum=75 /(8)$ \\
\hline Condition of ovaries & A & $\mathrm{c}$ & a & $\mathrm{a}$ & a & a & $?$ & $\mathrm{a} \rightarrow \mathrm{A}$ & $?$ & $a \rightarrow A$ & & \\
\hline Thorax length in $\mathrm{mm}$ & 0.94 & 0.94 & 0.92 & 0.87 & 0.86 & 0.84 & $?$ & 0.86 & $?$ & 0.90 & & \\
\hline
\end{tabular}

After queen removal:

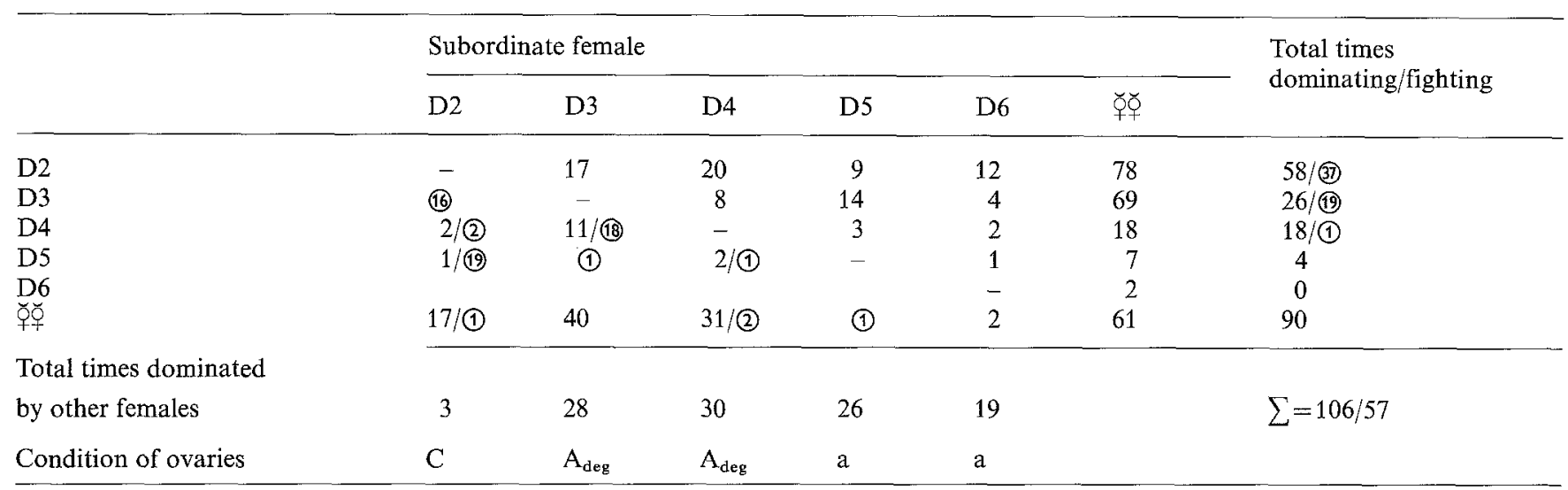

a In both cases workers pulled the female back into the nest

creased. In the presence of the fertile queen in D, workerworker dominance interactions had been noticed only six times in $13 \mathrm{~h}$ of observation. On the first few days after the removal of the queen, fifty such aggressive acts were recorded during $5 \mathrm{~h}$ observation (Table 7, Fig. 1). During this period, workers were seen feeding on eggs seven times, which never had occurred in the presence of the fertile queen.

In D, the females D2, D3, D4, and, less often, D5, engaged in fighting and dominance interactions, which resulted in a spatial separation. The female D2 remained near the egg pile, while D3 was at the nest entrance, and D4 outside the nest. D2 laid her first eggs approximately 8 days after queen removal. Outside of the colony, female D4 started ovipositing at the same time. In one instance, we observed that a worker picked up D4's egg from outside the nest and carried it to the brood pile within the colony, where it was investigated and licked by D2 and D6, but apparently not destroyed. D3 was never seen ovipositing. The frequency of aggressive acts, initiated by workers and directed toward female D2, decreased, whereas D4 was attacked more frequently (Fig. 1). Ten days after queen removal, D4 was pulled by several workers for hours, and her antennae and legs were torn off, resulting in her death 11 days after queen removal. D5 left the colony 3 days after the old queen had been removed and died 4 days later outside the nest, without having been involved in fights with workers. Thus, apparently only one of the five females in the colony, D2, successfully replaced the queen.

Similarly, the $\beta$-females in two other colonies, A2 and B3 (since B2 had died), became fertile about 1 week after the queen had been removed. B5 was heavily attacked by workers and left the colony 2 days after queen 
removal. The attacks continued outside the nest, and after 4 more days, B5 finally was killed.

When we put the still fertile original queens back into the three colonies 2 weeks after a replacement queen had started to lay eggs, they immediately were attacked by workers and were pulled and dragged out of the nest. Only in D was the original queen occasionally groomed by some workers, but after this she was attacked again. No encounters between original and replacement queens were observed. The original queens, although occasionally seen near the nest entrance, finally remained outside the nest. D1 was killed by workers 10 days after she had been put back into the colony.

The experiments were stopped about 4 weeks after queen replacement and the remaining females were dissected.

\section{Dissection of females}

Since most females were dissected after the original queens had been removed, the dissection results do not reflect the condition of their ovaries in the presence of the queen. However, in about 60 additional colonies from Tadoussac and other populations in Québec and New England, nearly always only one single female was fertile; the others were sterile with ovaries of type "a" or, less often, "c" (Heinze and Buschinger 1988). Thus it becomes very likely that each of our experimental colonies contained only one single fertile queen. The most probable actual conditions of the ovaries prior to queen removal are given in the tables.

In each queenright colony, only the highest ranking female had been fully fertile. Their ovarioles were distinctly elongated and contained numerous developing eggs and yellow bodies. The spermathecas of all the original queens were filled.

Most additional females were inseminated, with the exception of B4, C4, and D2. Permanently emigrating females, such as $\mathrm{Dh}, \mathrm{Dj}$, and $\mathrm{Dm}$, had elongated ovarioles with some developing eggs. In our experiments, however, none of these individuals had actually become fertile outside the nest.

After the original queen had been removed, in $A$ three (A2, A4, A7), B two (B3, B5), and D three (D2, D3, D4) females had started to oviposit; their ovaries were elongated and contained a few corpora lutea. However, when dissected, only the ovaries of the high ranking individuals A2, B3 (remember that B2 had died before queen removal), and D2 contained mature eggs. The ovaries of the others apparently had started to degenerate.

\section{Colonies with intermorphic and gynomorphic queens}

In the two colonies from St. Siméon that contained both intermorphic and gynomorphic females (E and F), no aggressive acts between females were observed, and no preference for an individual female by workers was deduced. Females typically appeared to ignore each other, although some, especially the gynomorph Fl and the intermorph $\mathrm{Fc}$, frequently groomed other females. The dissection of all the females showed that although no female had been fully fertile, most had laid eggs: their ovarioles were elongated and contained developing eggs and corpora lutea.

\section{Discussion}

In the nearctic ant Leptothorax sp.A, the reproductive competition among potential queens in colonies with multiple females is resolved through the formation of linear or near-linear dominance hierarchies. Aggressive interactions apparently are critically important in establishing and maintaining functional monogyny. After hibernation, the females engage in dominance and aversion behaviors similar to those observed among workers of Leptothorax (Macromischa) allardycei (Cole 1981), Protomognathus americanus (Franks and Scovell 1983), and Harpagoxenus sublaevis (Bourke 1988). Though dominance interactions have been reported from females in incipient colonies of ants (Hölldobler and Taylor 1983; Fowler and Roberts 1983; Hölldobler and Carlin 1985) and aggression has been observed among females in apparently polygynous colonies (Evesham 1984), this is the first time that a dominance hierarchy among inseminated females in mature colonies of ants has been documented.

The intermorphic females of Leptothorax sp.A are only a little larger in size than workers (Heinze and Buschinger 1987), and their thorax perhaps does not contain enough reserves to guarantee a successful colony foundation in the short period between mating in late July and the first snowfall in September. Instead of founding colonies on their own, many young intermorphic females return into their mothers' nests after mating, where they may stay for several breeding cycles without becoming fertile. About one-third of all colonies collected in Northeast America contained sterile, inseminated females in addition to one fertile intermorphic queen (Heinze and Buschinger 1988). The fertile queen is the top ranking individual in a hierarchy, which is established by aggressive interactions. She is groomed and fed significantly more often than other females. Our data suggest that she inhibits egg laying in subordinates by antagonistic behavior, at least during the first weeks after the end of hibernation. Later in the year, when the dominant $\alpha$-female has become fully fertile, physical aggression perhaps is replaced by a pheromonal queen control. In one colony that could be observed only several weeks after the end of hibernation, the dominant individual had already become physogastric and almost never engaged in aggressive interactions. Queen pheromones are known to inhibit reproductive activity in workers in many ant species, such as Plagiolepis pygmaea (Passera 1980) and the weaver ants Oecophylla longinoda and O. smaragdina (Hölldobler and Wilson 1983). In Harpagoxenus sublaevis, a pheromonal queen control has been suggested, too, although high ranking workers in queenless colonies apparently suppress fertility in 
other workers by means of antennation bouts and biting (Bourke 1988). The inhibitive power of the queen has been found to be weak or absent in Leptothorax (Temnothorax) recedens (Dejean and Passera 1974) for several weeks after hibernation. In Leptothorax sp.A, a similar phenomenon could explain the comparatively low frequency of dominance behavior exhibited by the fertile intermorphic queen in D. As in Harpagoxenus sublaevis (Bourke 1988), queen pheromones might inhibit workerworker aggression. Workers were not individually marked in our experiments, but it seems probable that the observed hierarchies among females are only a small part of hierarchies, which include all ants in the colony. In contrast to other leptothoracines, in Leptothorax sp.A, selfishness in workers is difficult to explain in terms of reproductive success, since they apparently have lost the capability to lay fertile eggs and to produce males even in queenless colonies (Heinze, unpublished).

After removal of the fertile queen, several other intermorphs started to develop eggs in each nest, but functional monogyny was maintained by fights among females or between females and workers. Dissection data show that in all three colonies only the individual highest in rank successfully replaced the queen. Other intermorphs either were expelled by workers and - perhaps because they did not have a chance to escape from our laboratory nests - were finally killed, or their ovaries started to degenerate and did not contain any developing eggs. Whether a female is inseminated or not apparently does not influence her rank in the hierarchy. To our surprise, in one colony an uninseminated intermorph replaced the queen and dominated several inseminated females. Though capable of producing males, uninseminated females certainly do not play a major role in natural populations: uninseminated, but fertile females have been found only occasionally in the field, and they were usually accompanied by a fertile inseminated female (Heinze and Buschinger 1988).

Queen replacement is not the only strategy for a young female of Leptothorax sp.A to produce her own offspring. After the end of hibernation, a number of intermorphic females abandoned the maternal nests, perhaps to found colonies on their own. The emigration was often preceded by violent fights among females or between females and workers. Aggression and dominance interactions thus might lead to the establishement of new colonies. In the laboratory, fights frequently disturbed the whole colony; workers began to remove eggs from the brood pile, and on two occasions the queen was observed leaving the nest. In the field, these conflicts might eventually result in the division of a colony. Colony foundation by budding seems to have advantages for species living in habitats distributed in patches (Hölldobler and Wilson 1977; Rosengren and Pamilo 1983). There is evidence that in Québec, colonies of Leptothorax sp.A are founded by colony-fission or budding. Ten of 36 single-queened colonies of Leptothorax sp.A collected in early summer did not contain an old, fully fertile queen, but only a female whose ovaries contained newly developing eggs and no corpora lutea (Heinze and Buschinger 1988). The abundance of Leptothorax sp.A colonies with intermorphic queens suggests that a strategy combining hibernation in maternal colonies and colony foundation, perhaps by budding, in spring is highly successful on the isolated rocky outcrops along the St. Lawrence and Saguenay Rivers in Québec.

It is not yet known which characteristics determine an individual's rank in the hierarchy and whether correlations exist between the rank of a female and her behavior in spring. A low ranking individual may have a poor chance for a successful independent colony foundation, but may outlive the original queen or may become fertile after colony fission. In one of the studied colonies, the lowest ranking individuals, D4, D5, and D6, indeed showed only little tendency to emigrate, wheras higher ranking females permanently or temporarily left the nest. The observed return of high ranking females, such as D2, D3, and Dm, into the colony perhaps is an artifact due to conditions in the laboratory. On the other hand, given our knowledge about the fascinating colony foundation behaviors exhibited by some close relatives, the socially parasitic Leptothoracini (e.g., Buschinger $1968 \mathrm{~b}$; Buschinger and Klump 1988; Stuart 1984; Heinze 1989 b), it would be not very surprising if a high ranking female would actively try to replace the $\alpha$-female and usurp the role of the queen.

In homogeneous habitats, such as the extended, open coniferous forests of Grands Jardins National Park or near St. Siméon, Leptothorax sp.A is less common, and most colonies contain only one single gynomorphic queen instead of several intermorphs (Heinze and Buschinger 1988). Apparently winged females usually do not return into their mothers' nests after mating and found colonies solitarily. Nests with multiple gynomorphic females therefore are quite rare even in populations with a high percentage of gynomorphic queens (Heinze 1989c). In our colonies from St. Siméon, aggressive interactions, similar to those observed in the colonies from Tadoussac, were apparently absent. Several females were fertile, though none was fully physogastric and most of them had oviposited only at a rather low rate. According to previous observations, colonies with several gynomorphs or both types of females usually are functionally monogynous also (Heinze and Buschinger 1988). In a number of cases, up to three inseminated gynomorphs were found to be sterile in the presence of a fertile intermorph, and one colony contained five sterile, inseminated intermorphs in addition to one fertile, gynomorphic queen. Occasionally truly polygynous colonies of functionally monogynous species, such as Leptothorax sp.A or Formicoxenus nitidulus (Buschinger and Winter 1976) have been found, but how they originate is unknown. The studied colonies from St. Siméon apparently belong to this rare group. Further experiments might help to determine whether or not dominance hierarchies exist in nests with several gynomorphic females.

By adopting young inseminated females, the lifetime of a functionally monogynous colony becomes extended, but the $\alpha$-female retains exclusive control over reproduction. Functional monogyny thus combines the advantages of monogyny with those of polygyny (Tschinkel 
and Howard 1978). Nevertheless it seems to be restricted to a small number of quite specialized ants; it has been regularly found in only seven species of leptothoracine ants and occasionally in Solenopsis invicta (Tschinkel and Howard 1978). The functional monogyny observed in one laboratory colony of Myrmecina graminicola (Baroni-Urbani 1968) has been thought to be an artifact (Buschinger 1970). Functional monogyny in leptothoracines seems to be correlated with another rare phenomenon, queen polymorphism: only in one functionally monogynous species, Leptothorax gredleri, do intermorphic queens not occur. It still remains to be explained whether these correlations are caused by a closer phylogenetical relationship between the different species or by similar adaptations to special habitats. In other groups of ants, a functional monogyny maintained by physical aggression might be an instable strategy: In species with a large colony size or in polydomous species, competition among females might lead to the spatial separation of individuals and to oligogyny instead of functional monogyny, as in Iridomymrex purpureus (Hölldobler and Carlin 1985). A reproductive domination less complete than in functionally monogynous Leptothorax sp.A perhaps is more common. It is known that the reproductive success of individual queens in polygynous colonies may vary widely (e.g., Keller 1988), and in the fire ant, Solenopsis invicta, queens not only differ in the total number of offspring but also in the relative production of workers and female sexuals (Ross 1988). Though at least in part this variability can be explained by intrinsic physiological factors, in other cases subtle forms of behavioral dominance, such as differential oophagy (Gervet 1964), might lead to substantial differences in fecundity.

In Leptothorax sp.A, further studies with laboratorybred colonies, containing females of defined age and comparable numbers of workers and brood, will help to find out more about the development of hierarchies in colonies with both gynomorphs and intermorphs and the role of behavioral domination in colony foundation.

Acknowledgements. We thank N.F. Carlin, S.P. Cover, P.C. Frumhoff (all at Harvard University, Cambridge, MA), I.D. Chase (SUNY at Stony Brook, NY), R.J. Stuart (UVM, Burlington, VT), K.E. Linsenmair and B. Hölldobler (Universität Würzburg, F.R.G.), and four unknown referees for helpful comments on the manuscript. The study was in part financed by a grant of the NATO Science Council through DAAD to J.H. A short communication concerning preliminary results will be published separately.

\section{References}

Alloway TM, Buschinger A, Talbot M, Stuart R, Thomas C (1982) Polygyny and polydomy in three North American species of the ant genus Leptothorax Mayr (Hymenoptera: Formicidae). Psyche 89:249-274

Appleby MC (1983) The probability of linearity in hierarchies. Anim Behav 31:600-608

Baroni-Urbani C (1968) Domination et monogynie fonctionelle dans une société digynique de Myrmecina graminicola Latr. Insectes Soc 15:407-412

Bourke AFG (1988) Dominance orders, worker reproduction, and queen-worker conflict in the slave-making ant Harpagoxenus sublaevis. Behav Ecol Sociobiol 23:323-333
Brown WL (1955) The ant Leptothorax muscorum (Nylander) in North America. Entomol News 66:43-50

Buschinger A (1966) Untersuchungen an Harpagoxenus sublaevis Nyl. (Hym., Formicidae). II. Haltung und Brutaufzucht. Insectes Soc 13:311-322

Buschinger A (1968a) Mono- und Polygynie bei Arten der Gattung Leptothorax Mayr (Hymenoptera, Formicidae). Insectes Soc 15:217-226

Buschinger A (1968b) Untersuchungen an Harpagoxenus sublaevis (Nyl.) (Hymenoptera; Formicidae). III. Kopula, Koloniegründung, Raubzüge. Insectes Soc 15:89-104

Buschinger A (1970) Zur Frage der Monogynie oder Polygynie bei Myrmecina graminicola (Latr.) (Hym., Form.). Insectes Soc 17:177-182

Buschinger A (1973) The role of daily temperature rhythms in brood development of ants of the tribe Leptothoracini (Hym., Formicidae). In: Wieser W (ed) Effects of temperature on ectothermic organisms. Springer, Berlin Heidelberg New York, pp 229-232

Buschinger A (1974a) Mono- und Polygnie in Insektensozietäten. In: Schmidt GH (ed) Sozialpolymorphismus bei Insekten. Wissenschaftliche Verlagsgesellschaft, Stuttgart, pp 862-896

Buschinger A (1974b) Experimente und Beobachtungen zur Gründung und Entwicklung neuer Sozietäten der sklavenhaltenden Ameise Harpagoxenus sublaevis (Nyl.). Insectes Soc 21:381406

Buschinger A (1979) Functional monogyny in the American guest ant Formicoxenus hirticornis (Emery) (=Leptothorax hirticornis) (Hym., Form.). Insectes Soc 26:61-68

Buschinger A, Alloway T (1978) Caste polymorphism in Harpagoxenus canadensis M.R. Smith (Hym., Formicidae). Insectes Soc $25: 339-350$

Buschinger A, Heinze J (1988) Practical tube nests for transportation and mailing of live ant colonies. Insectes Soc 35:206-208

Buschinger A, Klump B (1988) Novel strategy of host-colony exploitation in a permanently parasitic ant, Doronomyrmex goesswaldi. Naturwissenschaften 75:577-578

Buschinger A, Winter U (1975) Der Polymorphismus der sklavenhaltenden Ameise Harpagoxenus sublaevis (Nyl.). Insectes Soc 22:333-362

Buschinger A, Winter U (1976) Funktionelle Monogynie bei der Gastameise Formicoxenus nitidulus (Nyl.) (Hym., Form.). Insectes Soc 23:549-558

Buschinger A, Francoeur A, Fischer K (1980) Functional monogyny, sexual behavior, and karyotype of the guest ant. Leptothorax provancheri Emery (Hymenoptera, Formicidae). Psyche $87: 1-12$

Carlin NF, Hölddobler B, Gladstein DS (1987) The kin recognition system of carpenter ants (Camponotus spp.). III. Within-colony discrimination. Behav Ecol Sociobiol 20:219-227

Cole BJ (1981) Dominance hierarchies in Leptothorax ants. Science 212:83-84

Dejean A, Passera L (1974) Ponte des ouvrières et inhibition royale chez la fourmi Temnothorax recedens (Nyl.) (Formicidae, Myrmicinae). Insectes Soc 21:343-356

Dobrzański J (1966) Contribution to the ethology of Leptothorax acervorum (Hymenoptera: Formicidae). Acta Biol Exp (Warsaw) $26: 71-78$

Evesham EJM (1984) Queen distribution movements and interactions in a semi-natural nest of the ant Myrmica rubra L. Insectes Soc 31:5-19

Fletcher DJC, Ross KG (1985) Regulation of reproduction in eusocial Hymenoptera. Ann Rev Entomol 30:319-343

Fowler HG, Roberts RB (1983) Anomalous social dominance among queens of Camponotus ferrugineus (Hymenoptera: Formicidae). J Nat Hist 17:185-187

Francoeur A (1986) Deux nouvelles fourmis néarctiques: Leptothorax retractus et Leptothorax sphagnicolus (Formicidae, Hymenoptera). Can Entomol 118:1151-1164

Franks NR, Scovell E (1983) Dominance and reproductive success among slave-making worker ants. Nature 304:724-725 
Gervet J (1964) Le comportement d'oophagie differentielle chez Polistes gallicus L. (Hymen., Vesp.). Insectes Soc 11:343-382

Heinze J (1989a) A biochemical approach toward the systematics of the Leptothorax "muscorum" group in North America (Hymenoptera: Formicidae). Biochem Syst Ecol 17:595-601

Heinze J (1989b) Leptothorax wilsoni n.sp., a new parasitic ant from eastern North America (Hymenoptera: Formicidae). Psyche 96:49-61

Heinze J (1989c) Alternative dispersal strategies in a North American ant. Naturwissenschaften 76:477-478

Heinze J, Buschinger A (1987) Queen polymorphism in a nonparasitic Leptothorax species (Hymenoptera, Formicidae). Insectes Soc 34:28-43

Heinze J, Buschinger A (1988) Polygyny and functional monogyny in Leptothorax ants (Hymenoptera: Formicidae). Psyche $95: 309-325$

Heinze J, Buschinger A (1989) Queen polymorphism in Leptothor$a x$ sp.A: its genetical and ecological background (Hymenoptera: Formicidae). Insectes Soc 36:139-155

Herbers JM (1986) Effects of ecological parameters on queen number in Leptothorax longispinosus (Hymenoptera: Formicidae). J Kansas Entomol Soc 59:675-686

Hölldobler B (1962) Zur Frage der Oligogynie bei Camponotus ligniperda Latr. und Camponotus herculeanus L. (Hymenoptera: Formicidae). Z Angew Entomol 49:337-352

Hölldobler B, Carlin NF (1985) Colony founding, queen dominance and oligogyny in the Australian meat ant Iridomyrmex purpureus. Behav Ecol Sociobiol 18:45-58

Hölldobler B, Taylor RW (1983) A behavioral study of the primitive ant Nothomyrmecia macrops Clark. Insectes Soc 30:384 401

Hölldobler B, Wilson EO (1977) The number of queens: an important trait in ant evolution. Naturwissenschaften 64:8-15

Hölldobler B, Wilson EO (1983) Queen control in colonies of weav- er ants (Hymenoptera: Formicidae). Ann Entomol Soc Am $76: 235-238$

Keller L (1988) Evolutionary implications of polygyny in the Argentine ant, Iridomyrmex humilis (Mayr) (Hymenoptera: Formicidae): an experimental study. Anim Behav 36:159-165

Pardi L (1940) Richerche sui Polistini. 1. Poliginia vera ed apparente in Polistes gallicus L. Atti Soc Toscana Sci Nat 49:3-9

Passera L (1980) La fonction inhibitrice des reines de la fourmi Plagiolepis pygmaea Latr.: rôle des pheromones. Insectes Soc 27:212-225

Rosengren R, Pamilo P (1983) The evolution of polygyny and polydomy in mound-building Formica ants. Acta Entomol Fenn 42: $65-77$

Ross KG (1988) Differential reproduction in multiple-queen colonies of the fire ant Solenopsis invicta (Hymenoptera: Formicidae). Behav Ecol Sociobiol 23:343-355

Stuart RJ (1984) Experiments on colony foundation in the slavemaking ant Harpagoxenus canadensis (M.R. Smith) (Hymenoptera: Formicidae). Can J Zool 62:1995-2001

Torossian C (1958) L'aliment proctodeal chez la fourmi Dolichoderus quadripunctatus (Dolichoderidae). C R Acad Sci 246:35243526

Torossian C (1978) La ponte d'oeufs abortifs chez les ouvrières de la fourmi Dolichoderus quadripunctatus. Soc Hist Nat Toulouse Bull 114:207-211

Tschinkel WR, Howard DF (1978) Queen replacement in orphaned colonies of the fire ant, Solenopsis invicta. Behav Ecol Sociobiol $3: 297-310$

Wilson EO (1974) Aversive behavior and competition within colonies of the ant Leptothorax curvispinosus. Ann Entomol Soc Am 67:777-780

Wilson EO (1976) A social ethogram of the neotropical arboreal ant Zacryptocerus varians (Fr. Smith). Anim Behav 24:354 363 